Jusmal lemiah
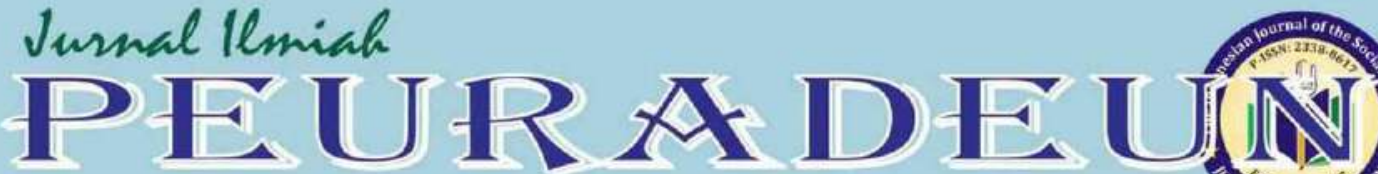

Vol. 8, No. 3, September 2020

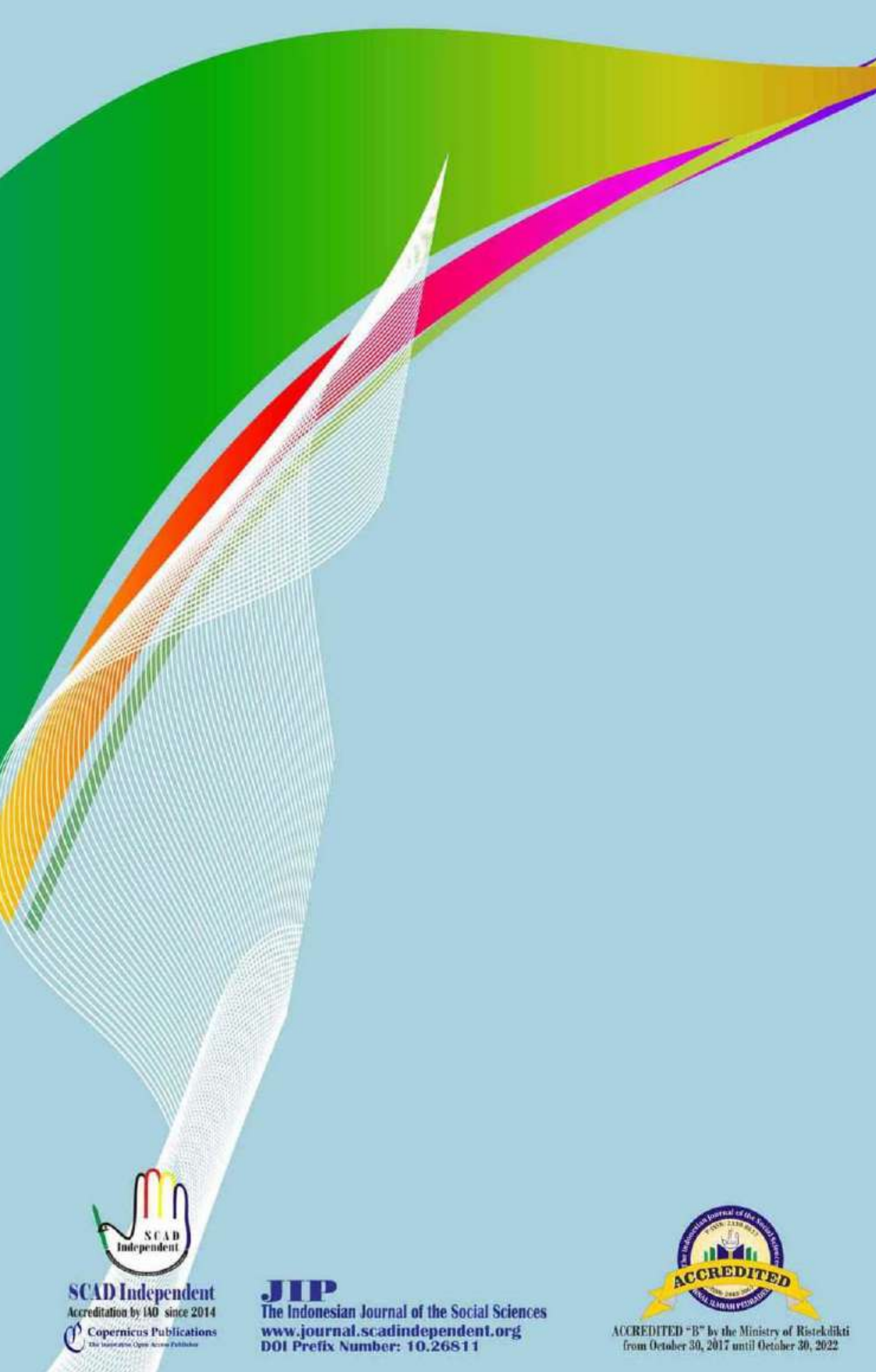

\section{Clarivate Analytics}

Emerging Sources Citation Index Web of Science ${ }^{\mathrm{TM}}$

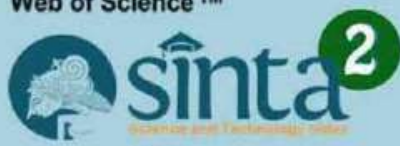

INDEX $\circledast$ COPERNICUS www.journal.scadindependent.org Dot Prefix Number: 10.2681 


\author{
JURNAL ILMIAH PEURADEUN \\ The Indanesian Journal of the Sacial Sciences \\ p-ISSN: 2338-8617/ e-ISSN: 2443-2067
}

www.journal.scadindependent.org

\author{
Vol. 8, No. 3, September 2020
}

Pages: 649-662

\title{
Problems of Sources for the Reconstruction of the History of Islam in Yauri Emirate
}

\author{
Suwaiba Salihu' ${ }^{\text {\& Atiku Garba Yahaya }}{ }^{2}$ \\ 1,2Usmanu Danfodiyo University, Sokoto, Nigeria
}

\begin{abstract}
Article in Jurnal Ilmiah Peuradeun
Available at : https://journal.scadindependent.org/index.php/jipeuradeun/article/view/575

DOI $\quad$ : http://dx.doi.org/10.26811/peuradeun.v8i3.575
\end{abstract}

\begin{abstract}
How to Cite this Article
APA : Salihu, S., \& Yahaya, A. (2020). Problems of Sources for The Reconstruction of The History of Islam in Yauri Emirate. Jurnal Ilmiah Peuradeun, 8(3), 649-662. doi:10.26811/peuradeun.v8i3.575
\end{abstract}

Others Visit : https://journal.scadindependent.org/index.php/jipeuradeun

Jurnal Ilmiah Peuradeun (JIP), the Indonesian Journal of the Social Sciences, is a leading peer-reviewed and openaccess journal, which publishes scholarly work, and specializes in the Social Sciences that emphasize contemporary Asian issues with an interdisciplinary and multidisciplinary approach. JIP is published by SCAD Independent and published 3 times of year (January, May, and September) with p-ISSN: 2338-8617 and e-ISSN: 2443-2067. Jurnal Ilmiah Peuradeun has become a CrossRef Member. Therefore, all articles published will have a unique DOI number. JIP has been accredited by the Ministry of Research Technology and Higher Education Republic of Indonesia (SK Dirjen PRP RistekDikti No. 48a/KPT/2017). This accreditation is valid from October 30, 2017 until October 30, 2022.

JIP published by SCAD Independent. All articles published in this journal are protected by copyright, licensed under a CC-BY-SA or an equivalent license as the optimal license for the publication, distribution, use, and reuse of scholarly works. Any views expressed in this publication are the views of the authors and not of the Editorial Board of JIP or SCAD Independent. JIP or SCAD Independent cannot be held responsible for views, opinions and written statements of authors or researchers published in this journal. The publisher shall not be liable for any loss, actions, claims, proceedings, demand, or costs or damages whatsoever or howsoever caused arising directly or indirectly in connection with or arising out of the use of the research material. Authors alone are responsible for the contents of their articles.

JIP indexed/included in Web of Science, MAS, Index Copernicus International, Sinta, Garuda, Moraref, Scilit, Sherpa/Romeo, Google Scholar, OAJI, PKP, Index, Crossref, BASE, ROAD, GIF, Advanced Science Index, JournalTOCs, ISI, SIS, ESJI, SSRN, ResearchGate, Mendeley and others. 


\title{
PROBLEMS OF SOURCES FOR THE RECONSTRUCTION OF THE HISTORY OF ISLAM IN YAURI EMIRATE
}

\author{
Suwaiba Salihu1 \& Atiku Garba Yahaya ${ }^{2}$ \\ 1,2Usmanu Danfodiyo University, Sokoto, Nigeria \\ ${ }^{1}$ Contributor Email: suwabas01@yahoo.com
}

Received: May 30, 2020

Accepted: Aug 12, 2020

Published: Sep 30, 2020

Article Url: $\underline{\text { https://journal.scadindependent.org/index.php/jipeuradeun/article/view/575 }}$

\begin{abstract}
The paper examined the challenges encountered during data collection in a field survey. There existed some variations between oral narratives and documented evidence on the history of Islam in Yauri Emirate. Management of such conflicting data from primary and secondary sources in academic research was one of the most tasking endeavors because it required corroboration people who witnessed the events and experts with authentic versions of the historical development of the event under investigation. Reconciling such data has become a daunting task for the researchers however when the researcher resorted to verification of the data collected from the experts and available old people in the community concerned, both data could be harmonized and produced robust findings in the reconstruction of Islamic history in Yauri Emirate.
\end{abstract}

Keywords: Reconstruction; History of Islam; Yauri Emirate; Challenges. 


\section{A. Introduction}

In the name of Allah, the Beneficent the Merciful, may the peace and blessing of Allah be upon His noble Messenger, Prophet Muhammad (May the peace and blessings of Allah be upon him).

Historical scholars of whatever persuasions be it Islamic or social historians need sources to elicit information about their subject or object of investigation. Consequently, there are many types of sources in which a researcher can elicit data which books, letters, newspapers, films documentaries, pamphlets, booklets, speeches, photographs, evidential monuments, oral accounts, and so forth. Ultimately, all sources are divided into two distinct categories namely: primary and secondary sources. It is on this premise that the researchers conducted the study on Yauri Emirate.

Although primary and secondary sources of the history of Yauri have been quite helpful, essential, and indispensable, some of them are not wholly reliable in as much as the history of Islam and the extent of Islamic influence in the Emirate are concerned. Shafiee (2015) opines that historical research of this nature is interested in eliciting and appraisal of data to either explain or describe previous events or to understand or discuss actions and phenomenon that occurred previously. Therefore, is an effort or attempt to reconstruct previous event(s) in a particular time or epoch either partial or complete for the sake of knowledge and preservation of the history of any kind which relates to the subject?

Both documented evidence and oral accounts about the history of Islam in Yauri Emirate has it that according to Abubakar (2015) Islam was introduced to Yauri as far back as the 17th century or even earlier, it continued to be the religion of the Hausa people living in the area for quite a long time. The non-Hausa elements in the territory (Kambari, Dukkawa, Gungawa, and Lopawa), did not for quite sometimes show any form of interest towards Islam probably since the rulers of Yauri neither encouraged the religion nor forced anybody to abandon paganism.9 The level of accepting Islam amongst the non-Hausa elements therefore 
consistently remained unimpressive for quite sometimes. The spread of Islam among the native people of Yauri Emirate was consequent upon four major developments in the area: i.e. the activities of Muslim clerics (Malamai), Sardauna's Conversion Campaign, the role played by the Muslim youths, as well as Islamic religious organizations like Jama'atu Nasirul Islam (J.N.I), Jama'atu Izalalil Bidi'ah Wa Ikamatu Bid'ah (JIBWIS), Federation of Muslim Women Organization (FOMWAN), etc.

However, Wara (2016) provided a similar but different account on the coming of Islam to some parts of Yauri Emirate, specifically, a place called Birnin Yauri or Yawuri. Commercial activities between Hausa Muslims and indigenous people of the area mostly Kambari ethnic group, persuaded the latter to embrace Islam as their religion. Wara (2016) further states that from the beginning of the 15th century up to the middle of the 18th century, the town of Birnin Yawuri had experienced the presence and settlements of different groups of Hausa people who persisted in practicing their Hausa culture. Thus Birnin Yawuri appeared as the meeting point of the Hausa community who were mainly seasonal traders from all parts of Hausaland. It was this development that eventually led to the establishment of the Hausa rule first witnessed at Birnin Yawuri as their political headquarters of the newly created kingdom of Yawuri.

This also ensured the planting of Hausa rule at Agwara, the then seat of the Kambari Kingdom of Maginga, about 30 miles south of Birnin Yawuri by the first half of the the17th century.6 In 1807, agreements of neutrality and passage were reached between Sheikh Uthman Ibn Fodio and Sarkin Yauri Muhammadu Albishir Dan $\mathrm{A}^{\mathrm{c} i}$ that rendered free movement of Hausa Muslims into the areas of Yauri and Maginga kingdoms.

Therefore, is important to the stated rationale behind this paper were discussions and interactions between the lead author and supervisors in the process of carrying out a study titled "Islamic Factor in the Evolution of Yauri Emirate". It is not the task of collecting data and interpreting the same that possess many challenges, rather, it is the task of 
reconciling the available sources of data vis-à-vis the existing realities on the ground which was the most daunting. The aim of this paper to discuss some of the problems encountered in the process of carrying out historical research regarding Islam in a rudimentary society like Yauri Emirate. The significance of this article is twofold: it would contribute to the existing literature on Islamic History for scholars of History and Islamic Studies in Northern Nigeria. Also, it would help researchers who intend to carry out a study in Yauri Emirate to know the task ahead of them and prepare on how to collect and manage data as well as data mining.

\section{B. Method}

The study is a descriptive research which is to describe previous events regarding the focus of this study in Yauri Emirate. Mixed methods of data collection were utilized which enabled the researchers to collect both primary and secondary data. For primary data, the qualitative method (In-Depth Interviews) was conducted to obtain oral accounts regarding the phenomenon investigated. Similarly, for a secondary source of data, documented literature was consulted for the study. The rationale for the adoption of such techniques of data collection is that historical research is quite different from experimental research and survey study. This is in line with the view of Shafiee (2015) that, in historical research, there is no manipulation or control of variables as it is obtainable in an experimental type of research.

Participants for the In-Depth Interviews (IDI) were selected based on the use of the purposive sampling method. The purposive sampling technique, also called judgment sampling, is the deliberate choice of an informant due to the qualities the informant possesses. It is a non-random technique that does not need underlying theories or a set number of informants. Simply put, the researcher decides what needs to be known and sets out to find people who can and are willing to provide the information by knowledge or experience (Bernard, 2002, Lewis \& Sheppard, 2006). Purposive sampling is especially exemplified through the key informant technique (Bernard, 2002, Garcia, 2006). Based on the 
foregoing explanation, participant's five participants were selected for the IDI from the three Local Government Areas under Yauri Emirate. Elderly men who possess in-depth historical knowledge of Islam in the areas were identified with the help of informants from the areas and they agreed to grant an interview. Data in this study are information elicited from the research participants and secondary material from the archives and the internet. The data from the aforementioned sources are analyzed in prose style which is one of the styles in qualitative data presentation and analysis. This is an attempt by the researchers to share their field experiences during a cross-sectional study in Yauri Emirate for the benefit of the scientific community and policymaking.

\section{Result and Discussion}

The aim of this paper is not present and discusses the findings of the study because it is not an empirical study. Therefore, instead, this section provides the thematic issues and challenges regarding the history of Islam in Yauri Emirate, and below are the issues discovered. There is no conventional discussion of the major findings as it is obtainable or found in virtually all empirical studies.

\section{Thematic Issues in the History of Islam in Yauri Emirate}

Modern Yauri Emirate is part of the four (4) Emirates that made up present Kebbi State, North-western Nigeria. The Emirate comprises three (3) Local Government Areas namely: Yauri, Ngaski, and Shanga. These make up its fifteen (15) districts with the Emir of Yauri sitting atop of the fifteen (15) District Heads.

Historically, part of Hausaland, nevertheless the historiography of early Islamic influence in Yauri was to a large extent problematic. Writing on the introduction of Islam in Yauri, one of the finest authorities on Yauri noted that there is a lack of materials on how Islam was introduced into Yauri (Adamu, 1968). Conflicting accounts are accorded the Yauri kinglist from which speculative inferences were made as to the introduction of 
Islam in Yauri. From the fifth $\left(5^{\text {th }}\right)$ King to which the Kingdom owed its name, Yauri (1505-1531) down to the nineteenth (19th) King Ibn Ibrahim (1689-1709) rulers of Yauri who came in between them have been associated with Islam in one way or another. Adamu (2000), has admitted in his treatment of the Yauri Kingdom in the 19th century that conflicting reports abound concerning the introduction of Islam in ancient Yauri. While some accounts alluded to the fifth (5th) King (Sarki Yauri) with its introduction, other accounts alluded to the reign of Sarki Jerabana II (1620-1663), the eleventh (11) King, with its introduction and promulgation as a state religion. Hogben and Kirk-Green (1967), alluded to a certain wandering Mallam from Dabbakar at Magori with the introduction of Islam in Yauri. This Mallam was also cast as the reputed father and progenitor of the Jerabana dynasty in Yauri.

Caliph Muhammadu Bello, son of Shaykh Uthman Ibn Foduye and leader of the Sokoto Caliphate, wrote in one of his famous books - InfakulMaysur(Bello, 1964)that before the Jihad of 1804, the Yauri region was inhabited by pagan tribes who were later on ruled and Islamised by a just ruler named Sarki Suto. The historical dilemma posed by the advent of Sarki Suto as the first ruler of Yauri was aptly captured by Adamu. The name was never on Yauri King-list neither was it in the faintest memory of the people of the area (Adamu, 1968).

The 1804 Islamic reform movement in Hausaland was also according to sources, marginally felt in the cultural and religious life of the people of Yauri Kingdom; one, due to the dhimmi (trusteeship) status of Yauri in its relation with Sokoto Caliphate; and two, given its topography with its difficult and riverine terrains as well as the efficacy of some of its water deities (Bunza, 2006).

At the turn of the twentieth $\left(20^{\text {th }}\right)$ century, what was clear in the area was that a significant number of the Gungawa, Dukkawa, and Shangawa groups remained largely un-Islamised. The area thus attracted the interest of Christian missionaries of the colonial era who succeeded in converting a large number of people in the area and building mission schools and churches in the process (Mansur, 2010). 
The full Islamization effort in Yauri has to await the second half of the $20^{\text {th }}$ century with the commencement of Sardauna's Islamization campaigns in Northern Nigeria between 1961 and 1965. Thus, against the backdrop of pre-existing claims of Islamic influence in Yauri vis-a-vis the researchers' field trips, observations, and interviews, one is tempted to say that the necessary evidential basis for such claims are somewhat lacking. To these researchers, establishing the chronological sequence of Islamic activities in Yauri beginning from the advent of the Emirate system in 1904 was in itself daunting.

Wara (2015) shows that the Islamic Education Trust (IET) has been instrumental in the spread of Islam and its knowledge after the demised of Sir Ahmadu Bello (Sardauna). IET, a non-governmental organization has been involved in the activities of teaching and preaching to nonMuslims in Yauri Emirate especially among Kambari people. The organization (IET) was established in 1969 to continue with the work started by Sir. Ahmadu Bello in the spread of Islam to unbelievers in the entire Northern Nigeria. This is because the spread of Islam had faced a major setback after the assassination of Sir. Ahmadu Bello (Sardauna) on 15 th January 1966. Among the setbacks was, the Kambari who were left ignorant regarding the proper observance of the principles of Islamic teachings. Consequently, some of the Kambari returned to animism until the appearance of the IET in Yauri Emirate in 1970. This helped in reawakening the glory of Islam among the Kambari. The organisation drew a considerable number of the Kambari into Islam and imparted practical Islamic knowledge on the Kambari Muslim converts.

\section{The Challenges Encountered During Data Collection in Yauri Emirate}

Despite the usefulness of primary sources to the research, the arrays of primary sources available to the researchers are not without their problems. Although the researcher has no difficulty with regards to access to informants, yet the quality of the information left much to be desired. Some of the reasons for this state of affairs include: 
a. Death - most people who were at the centre of the issue under investigation have died. The researcher was therefore made to rely on their progenies to inform on what they possibly know. For instance, account on Islamisation effort during colonial period was very sketchy as far as oral information is concerned.

b. Old ages - has rendered some of the oral accounts not so reliable. This is especially true of the very old people who could hardly recall all that transpired during their youthful years due to loss of memory. This also explains why there are conflicting accounts regarding some aspects of the history of Yauri including of course, the Islamisation campaigns/conversions in the area.

c. Problems of record keeping - the custodians of the records especially the elderly, Islamic scholars, and traditional rulers kept no records of conversion activities in the area prior to the ascension of the throne by the incumbent Emir Dr. Muhammad Zayyanu Abdullahi. As a result, names and addresses of previous converts in the areas were not available.

d. Uncooperative attitude of some traditional rulers - this is especially true of some village and ward heads who seem uninterested in answering or divulging useful information. It thus became difficult to obtain any data on non-Muslims living in communities where these traditional rulers are. The reasons for the actions of some of these traditional rulers, as the researcher gathered from some informants, are that the rulers feared that their Kambari and Dukkawa subjects might emigrate to Kambari speaking parts of Niger State should they be exposed to anything bordering on the question of their religious identity (Mallam Lawali, 2011). These traditional rulers were not only stumbling blocks to the researcher, they were equally a big obstacle to Islamic proselytisation and conversion in the area.

e. Uncooperative attitude of non-Muslims in the area - it is a herculian task to attempt to obtain information from non-Muslim Kambari and Dukkawa people in the area giving the non-cooperation of some of 
their rulers. Hence, most of the data on non-Muslims in Yauri were solely obtained from certain district heads and Islamic scholars. The bulk of the data on Muslim reverts or converts came from the office of the Emir of Yauri.

f. Problem of Christian Missionaries: like uncooperative traditional rulers, Christian missionaries in the area have equally succeeded in making it difficult to obtain information regarding the number or prevalence of non-Muslims. Apart from their successes in converting the Kambari to Christianity, they tacitly encouraged the uninitiated Kambari to keep silent.

The problem with all these is the creation of missing links in primary data as well as problem of establishing chronology of events in the period beginning from 1904 which marked the beginning of the Emirate system in Yauri.

\section{Problems with Secondary Sources}

These sources often provide more information about an event or events, a period or a subject of research than primary sources. For instance, when we take jihadists literature such as Shaykh Muhammad Bello's "Infakul-Maysur", the author's view on Yauri and the level of penetration of Islam therein among its people is sketchy to say the least. Left to the work alone, (Bello, 1964) Yauri will be seen as a purely pagan society being ruled by a 'just, Muslim ruler'.

On the part of the colonial writers, it is an open secret that their literature was reflective of the colonial establishment's mentality in its relation with its conquered territories and subjects. Most of their commissioned anthropological studies were for a purpose - to discredit, to discard and/or to defend certain colonial policies and/or actions. For instance, for Christian missionaries to be allowed to deploy to Yauri, the colonial writers-cum-administrators must show the admissibility for such colonial acts as to show that there was little or no Islam in Yauri (Harris, 1930). The post-colonial nationalist writers such as Professor Mahdi 
Adamu (who can also be termed 'indigenous' and a leading authority on Yauri history) can equally be influenced by factors beyond their control (Mahdi, 2014).

People who write secondary sources have access to more information about a certain historical event and have time to analyse the evidence more carefully. This is because they have at their disposals a cumulative sum of varied primary sources/accounts. Although a secondary author can consider evidence with the benefit of hindsight, such a person is still subject to bias and prejudice. A common mistake made by such authors is that some approach their topic with a preconceived notion, or a conclusion already formed about their subject of investigation (Mahdi, 2014).

Secondary authors are also open to many influences, including socioeconomic position, and philosophical, political, and religious outlooks. These outside influences can shape how a scholar views a particular topic. Thus, whether consciously or unconsciously, an author can select facts to better fit his or her argument.

Secondary sources on the history of Yauri are in themselves heavily dependent on primary oral sources, jihadist literature, and to a large extent on colonial literature. A combination of these as formed the basis of Mahdi's work on Yauri are also replete with a number of unanswered questions. The history of coming and spread of Islam in Yauri still remain controversial. So also, Yauri - Sokoto relations were very cordial in the $1^{\text {th }}$ century. Little wonder posers are still being raised as to the first appearance of Islamic influence in the area; first Muslim ruler/rulers of Yauri; extent of Yauri-Sokoto relation in the 19th century and the extent of Islamic penetration in Yauri among others.

It is a serious issue when post-independence nationalist scholars such as Mahdi, tend to clash with colonial writers (such as Temple, Hogben and Kirk-Greene among others). This only tends to compound the challenges for contemporary researchers who aimed at striking a balance or reconciling the two where possible. Such has been the fate of this research. 


\section{Handling the Problems}

After the data collection, the primary data generated from the interviews transcribed verbatim and presented in thematic style or fashion. The secondary data were used to complement the primary data. Similarly, the researcher was consistently guided by an awareness of the social, political, and religious contexts of all sources of information by the supervisors. The researcher has stuck to the fundamental questions of who, what, where, when, and why - of all pieces of information gathered from both primary and secondary sources. This is because writers or informants are shaped by the society or culture in which they live (Yahaya, 1998). Also, people's position in society, early life, career, family, political and religious outlook were considered in weighing the reliability/authenticity of information obtained. The same applies to every piece of literature be it official, scholarly, or private to detect that which possess an element of objectivity, subjective bias, or prejudices. This feat was made possible by the researcher's identification of relevant informants with a deeper understanding of the study area.

The researchers have thus been able to subject the primary sources to secondary verification and (vice-versa). And where there are clear missing links as in Islamization activities of Emirs of Yauri before the Sardauna's conversion campaigns (1961-1965) and thereafter, the researcher has indicated accordingly (as we await outcomes of future research in the area).

\section{Conclusion}

Data collections for historical research which part of it rely on human memory need careful observation and verification. Also, there are variations of submissions, accounts, and explanations of events found in documented texts. Reconciling oral accounts based on human memories and varied documented relics is one of the difficulties encountered in the research of this nature. It is safe to conclude that problems encountered by researchers in the field vary from one place to another or from one 
environment to another, more so, the phenomenon of interest for investigation. In the case of Yauri, some of the challenges encountered and discussed above include the non-reliability of some primary and secondary data, missing links and lack of chronology in linking up one epoch to the other, the attitude of some people who are the supposed custodians of useful data and information and to some extent, financial and logistic challenges/limitation of the researcher.

Additionally, some of these challenges have affected and shaped the outcome or results of the work on Islamic Factor in the Evolution of Yauri Emirate. Therefore, over-reliance on primary oral information and the devotion of much time verifying and comparing the collected oral information with available secondary data enable the researcher to come with a verified data and sound conclusion on how Islam evolved in Yauri Emirate and identified some of the factors that aided such evolution and transformation to this epoch.

In this regard, the efforts of the researcher would be rewarding if a thorough and vigorous examination and verification of raw, interpretation, and analysis are done. Available oral narrations and secondary written documents could be reconciled to produce a wellresearched work for religious and academic purposes.

In sum, considering the existing challenges and obstacles in attempts to reconstruct the history of Islam in Yauri, it is the view of the researchers that more scholarly research should be undertaken by Yauri stakeholders and the academics to uncover hidden treasure of the ancient Hausa society and evolution of Islam in the area. This is would be a great development in the preservation of knowledge where oral narratives and documented evidence would be reconciled to produce unified historical accounts of Islam in Yauri Emirate.

\section{Bibliography}

Abubakar, Y. (2015). Islam in Yauri Emirate to the End of the 20th Century. Journal of Islam in Nigeria, (1):1, 131-140. 
Adamu M. (1968). "A Hausa Government in Decline: Yauri in the 19th Century". M.A. (History) Dissertation, ABU, Zaria.

Adamu S. (2000). A Brief History of Yauri. Kaduna: Master Prints.

Bernard HR. (2002). Research Methods in Anthropology: Qualitative and Quantitative Methods. 3rd edition. Walnut Creek, California: AltaMira Press.

Bunza, MU., (2006). Religious Tolerance in the Sokoto Caliphate: Lessons for the Nigerian State. In Bobboyi H., Yakubu A.M., (Eds.). The Sokoto Caliphate: History and Legacies, 1804-2004 Vol.2, Kaduna: Baraka Press

Bustamam-Ahmad, K. (2019). The Religious Imagination in Literary Network and Muslim Contestation in Nusantara. Jurnal Ilmiah Peuradeun, 7(2), 217-244. doi:10.26811/peuradeun.v7i2.344

Garcia G.S.C. (2006). The Mother-Child nexus: Knowledge and Valuation of Wild food Plants in Wayanad, Western Ghats, India. Journal of Ethnobiology and Ethnomedicine (2), 39.

Harris PG. (1930). Notes on Yauri (Sokoto Province), Nigeria. The Journal of the Royal Anthropological Institute of Great Britain and Ireland, 60, 283-334.

Hoghen, S.J., \& Kirk-Greene, A.H.M., (1967). An Introduction to the History of Islamic States of Northern Nigeria. Ibadan: University Press.

Lewis J.L. \& S.R.J. Sheppard (2006). Culture and Communication: can Landscape Visualization Improve forest Management Consultation with Indigenous Communities? Landscape and Urban Planning (77), 291-313.

Mahdi A., (2014). The Rise and Fall of Hausa Rule in Yauri and Maginga Kingdoms from about 1425 to 1913. Zaria, Ahmadu Bello University Press.

Mallam Lawali Ahmad Wali. (2018). Islamic scholar, and Preacher, Ngaski, interviewed at Ngaski, on 15t 09, 2018.

Mansur A. (2010). History of the Akimba Group of the Kambari people to the end of the 20 $0^{\text {th }}$ Century. M. A. (History) Dissertation, Usmanu Danfodiyo University, Sokoto-Nigeria.

Muhammadu B. (1282 A.H./ 1964 C.E). Infaqul-Maysur fi Tarikh bilad attakrur (np). 
Obasa, D., \& Adebule, J. (2017). The Challenges of Higher Education in Growing Dialogue Culture and Understanding Cultural Pluralism. Jurnal Ilmiah Peuradeun, 5(3), 401-414. doi:10.26811/peuradeun.v5i3.183

Shafiee, S. (2015). Historical Research: Chapter 7. Islamic Azad UniversityNajafabad: http://research.iaun.ac.ir/pd/shafieenahrkhalaji/pdfs/UploadFile_2857.pdf

Steinbach, M., \& Afroozeh, S. (2016). Comparative Education in the Educational Systems and Problems in Likenesses and Differences Between Regions of the World. Jurnal Ilmiah Peuradeun, 4(3), 333346. doi:10.26811/ peuradeun.v4i3.107

Suraju, S. (2019). The Menace of Moral Degenerations in Nigeria's Tertiary Institutions: Islamic Universities to the Rescue. Jurnal Ilmiah Peuradeun, 7(3), 433-454. doi:10.26811/peuradeun.v7i3.464

Wara M. A. (2016). The Development of Hausa-Muslim Culture in Kambariland under the British Colonial Rule, 1900-1960. World Scientific News (WSN) (28) 1-12.

Wara MA. (2015). The Islamisation Mission of Islamic Education Trust (IET) among the Kambari People, 1970-1980. African Journal of History and Archaeology, (1):8, 21-29.

Yahaya AG. (1998). Fieldwork and the student of History: An experience. Journal of Pakistan Historical Society, Vol. XLVI, No.4, 38-59. 